\title{
The Norwegian 1.Lecturer - Shunned or Lost and Found?
}

\author{
Stig Eriksen \\ Inland Norway University of Applied Sciences \\ Yngve Nordkvelle \\ Inland Norway University of Applied Sciences
}

\begin{abstract}
Norwegian higher education has for a number of years had a system of two career paths for academic teachers. The path requiring a doctoral thesis and qualifying via doing more research to a professoriate was moulded primarily at the University of Oslo. The other path became accepted at a later stage, and encompassed academics who won their merits through teaching primarily. The difference in status we describe by the two terms: "the high road and the low road". Our argument here is that these two careers are complementary, and that further work needs to be done to make the status and desirability of the two paths more equal. The paper aims at describing how a fuller acknowledgement of the "teaching" path from a lecturer to an elevated status of 1.lecturer will improve the quality of teaching and improve collaboration and co-creating of good programmes for dissemination and training in both disciplinary and professional studies. A professional doctorate dedicated for teachers in higher education might be the viable middle road.
\end{abstract}

Keywords: academic development, professional doctorate, status, inequality, career paths

\section{INTRODUCTION}

The University of Oslo handled some of its growth issues from the early 20th century on, by hiring teachers with a good reputation from the "Gymnasium" (upper secondary schools) to take on teaching tasks and leave the professors more time to conduct research. After WW II this group grew in numbers and confidence and called for better salaries and working conditions (Nilsen, 2005). At this time there was rather unclear criteria for who could become professors, and the system was not unfamiliar with nepotism and favouritism, where the reigning professors decided who they wanted for which positions. During the 1950-ies the trajectories from entry positions to professoriates where straightened out and designated to peer assessment of earned qualifications, where research output became the measure of a successful career. The university lecturers, however, raised similar demands and wanted a more stringent definition of what lecturers could qualify for to reach a more prominent status. This points at the fundamental question: what is academic labour and how is it framed in different contexts?

Nilsen quotes a letter to the Ministry from the academic collegium at the University of Oslo (Nilsen, 2005, p.79) where the argument against an arrangement where all aspiring academics should seek promotion through research merits was aired. It might lead to: "...neglection of teaching and other institutional labour, which are similarly important functions in these positions". This sentiment expressed 
the viewpoints ventilated by two committees at the University of Oslo, the Steen-committee of 1950 and the committee led by professor Axel Strøm from 1959. The first committee emphasised the importance of the university lecturer and supported its existence and promotion. The second suggested a further formalisation into a stepwise route towards a promotion of the lecturer, making this trajectory similar to the conventional research path. In 1969, finally, the Ministry accepted the position of 1.lecturer formally and they reached a formal acknowledgement of any holder of the position being specialist teachers, more qualified than the ordinary lecturer, and with a defined position in the academic hierarchy (Nilsen, 2005).

Since then, the dichotomous order has been sustained in spite of numerous reforms and a substantial expansion of the higher education system. While the career path towards the professoriate has been strictly formalised into $\mathrm{PhD}$-programmes, and substantial efforts put into clarifying and regulating the design and procedures relating to doctoral schools and programmes, the practical path has hardly received any interest for the higher education bureaucracy, e.g. directorates or similar, and more importantly no financing scheme supporting this line of recruitment. The teacher unions, however, have strongly argued that the 1.lecturer also should have a path for reaching a top position equal to the professor. In 2006 the unions and government reached an agreement where the "Docent" title was re-established as an academic title, formally aligned with the "professoriate".

In the publicly financed higher education sector there are now 3226 persons employed as lecturers, who primarily have the career path via 1-lecturer to docent as the most attractive and viable (not private institutions). Obviously, not all of them have clear and ambitious plans for achieving a higher status. In a study recently performed at the largest university of Norway, Smith, Hakel \& Skjelestad (2020), the survey (response rate $43 \%, \mathrm{~N}=538$ ) showed that almost $50 \%$ of the university lecturers aimed for the practical trajectory to 1. lecturer, and almost $30 \%$ would seek to get a $\mathrm{PhD}$. If one, only for the interest of speculations, should generalise this desire to the entire population of Norwegian lecturers, there should be a pool of 1600 lecturers with the desire and potential for acquiring a 1. lecturership.

\section{The Low and High Roads}

The paper aims at sorting out some fundamental epistemological and ontological questions that emanates from this narrative of the competing positions in academia we choose to call the high road vs the low road. The authors may well serve as examples:

Associate professor Stig Eriksen was a trained electrician and is still keeping his certificate as such close to his heart. He took the low road to academia, entering work for the electricians union, then going through a serious injury at the workplace, and during a long period of rehabilitation and intensified work with teaching and coaching since 1985 in the «Labour movement association for further education» took his masters' degree in education in 1996. More work followed as a consultant and coach for diverse units in the labour movement, research and development work for business and public administration, as well as with the University of Oslo and other higher education institutions, before settling as an assistant professor or lecturer, as the formal term is in the Norwegian system, in a faculty for teacher training in 2005 . After eight years of intense teaching, with many academic responsibilities, participation in research activities as well as designing and performing coursework for the extension services of the university college, he applied successfully for 1. lectureship, after 28 years of experience of teaching and research and development work. Professor Yngve Nordkvelle was trained to become a teacher, taught in lower secondary schools and in social pedagogical work, before landing a masters' degree in education. He was recruited to do research on textbooks, classroom research and curriculum studies, before earning a position as Associate professor $(=\mathrm{PhD})$. He took 12 years to earn his second credentials to become a professor. 


\section{FIGURE 1}

\section{THE LOW AND THE HIGH ROAD}

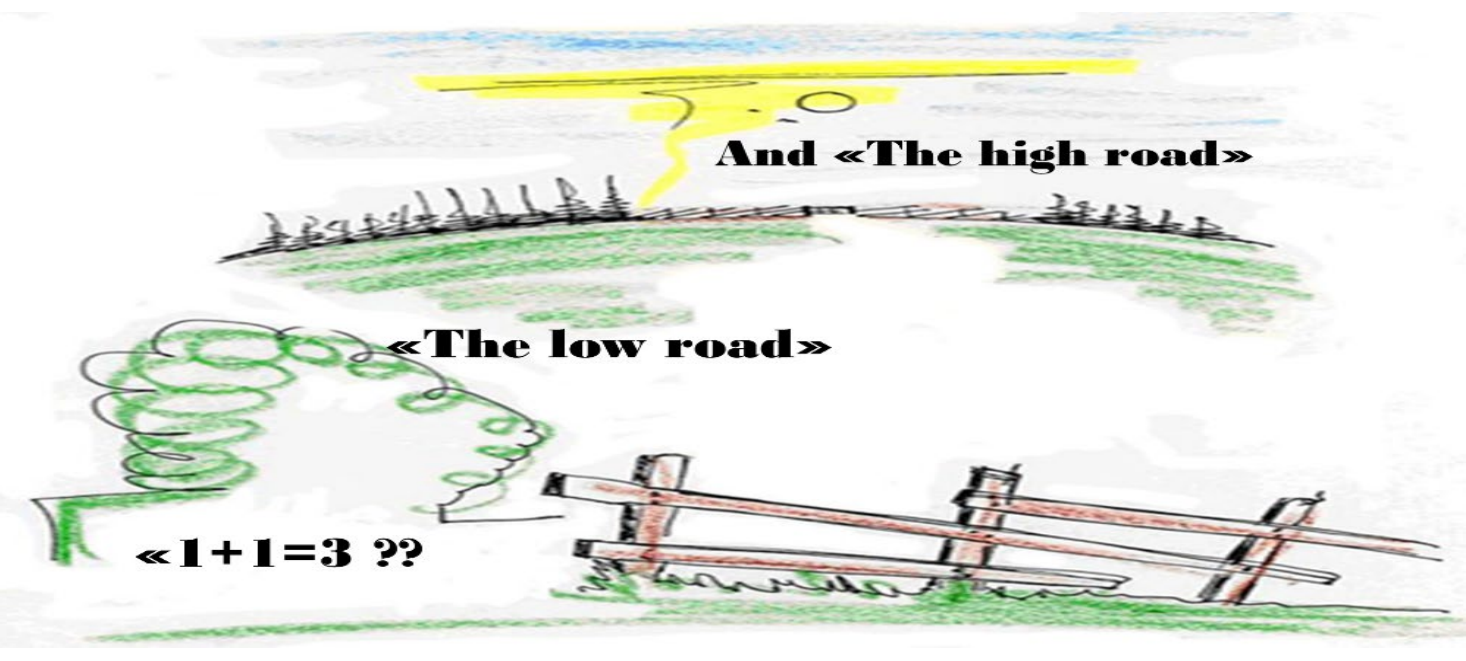

The common route to a position as associate professor/1.amanuensis is earning your $\mathrm{PhD}$. As of last fall a documented teacher training (teaching and learning in HE eq to 15 ECTS) or documented practice and other courses is necessary supplements. A second route is to provide evidence of advanced research background that complies with a PhD-thesis - plus similar educational merits.

The common route to 1.lecturer is a) practical or professional experience b) Masters' degree, c) experience from teaching in $\mathrm{HE}$ d) teacher training (similar to the 1. amanuensis). In addition the applicant has to provide a portfolio of R\&D experience documented and reflected - with same duration, - quality and analytical level as a $\mathrm{PhD}$, The portfolio may contain demonstrations of particular qualifications in the area of teaching and learning, as teaching merits that are documented and reflected upon (textbooks, compendia, course development).

FIGURE 2

THE TRADITIONAL AND ALTERNATIVE CAREER PATH

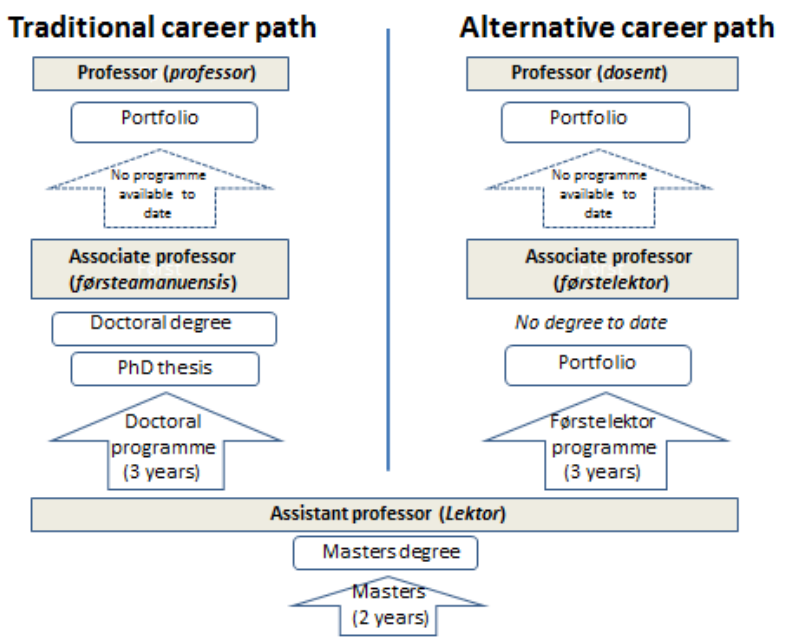

(Bjørke \& Habib, 2011)

The two trajectories illuminate that the teachers recruited to lecturer's positions are most often persons with some - or much practical experience before they return to HE, to complete a Master's degree, or to 
teach at BA-programmes in professional studies, primarily, but also in the disciplines. Those recruited to $\mathrm{PhD}$-programmes are in general significantly younger, although there are important differences between subjects, disciplines and institutions. A PhD candidate from the sciences domain would be ideally 31 years when the degree was completed, while the average is 35 years (NIFU-rapport 40/2009). The average time for employment (for all subjects) as 1.amanuensis is 44 years, and those applying for professoriats are 50 years on average (Kvittingen, 2008, p.16). Lecturers have a much longer path to reach their 1.lecturer-status -12 years on average and another 10 years to reach the top-position as dosent. The average age of a dosent is presently 61 years (Bachke, 2020).

\section{HOW DOES THE PHD AND THE 1.LECTURER'S PROFILE DIFFER?}

The present regulations offered from the Ministry of Higher Education reaffirms the tradition of the 1.lecturer as an expert teacher, who is qualified on the same criteria for educational development as if it were a PhD: Three years work of R\&D, systematically collected experience and reflected on professional grounds, rather than on conventional research. The regulation claims that to be qualified as 1.lecturer one needs to demonstrate R\&D-work which in quality and volume aligns to a doctoral thesis or a doctoral thesis in the arts. In addition the regulation states that special qualifications in teaching or other educational activities needs to be honoured. In the guidelines from the Norwegian Council for Higher education, the character of the 1.lecturer should not be exposed to "unnecessary academization" (authors' translation). In other words: it should be quite like a PhD-thesis, but different in orientation.

This implies that the procedures most doctoral candidates would go about to operationalize research questions, design strategies for sampling or collection of data, analysing data, and writing up for papers and reports, or what the Universities Norway (UN) calls the "Outside-looking-in-perspective", is inadequate for the 1.lecturer's documentation of qualifications, while "Inside-looking-out-perspective" would be more typical of the 1.lecturer (and docent) ${ }^{1}$.

Pettersen (2020) and Engelsen, Moser \& Wittek (2013) note that the interpretation of the regulations offered by the Ministry give few hints of what it might entail, as well as criteria for measuring its quality and standards. The negative description of "unnecessary academization" gives a vague direction. In the more explicit guideline offered by "Universities Norway" applicants are advised to provide a CV, copies of written papers, chapters etc., reports and other documentation - and finally a document stating the applicants experiences and views on how the competence stated is applicable to the area of teaching in HE, preferably presented as a narrative ${ }^{2}$. In a second set of guidelines the same institution offers slightly more philosophical descriptions of what the desired competency of a 1.lecturer might contain. It underlines that while the doctoral thesis has its emphasis on research, the documentation of a 1.lecturer should give emphasis to the development side of the "R\&D"-notion. It suggests that collaborative relations, administrative and institutional challenges would provide a similar complexity. Further it notes that this dimension of academic labour should display a "documented and reflected practice" or an "enacted knowledge". This material should also display a certain degree of novelty and innovation as well as being presented in an orderly and systematic fashion. It should also give evidence of significance for the application of the knowledge, the network and organizations it addresses and how the applicant shares knowledge and insights. Last, it explicates what "particular qualifications related to teaching" might entail, such as innovation in methods for teaching, planning, supervising or producing didactical material, course designs etc ${ }^{3}$.

One might say that these texts provide many ideas of what to include as valid material for an application, but a substantial number of those trying to apply find that the assessment committees often operationalize the criteria and principles in a haphazardly way. Members of committees are often poorly instructed about how the "different academization" can be assessed and validated. A general experience is that committees are consistently struggling with the riddle as to what the 1.lecturer's portfolio may contain, its genres and how to estimate quality and quantity. Together the keywords: non-academization, ordinary institutional work, documented and reflected practice, practitioners' knowledge offer us a very versatile, but unstable premise for the assessment of candidates. Often the members are keen representatives of the dominant and 
conventional research paradigm and has little respect for the "insider-epistemology" of the 1.lecturers' context for academic labour ${ }^{4}$.

This lack of a distinct and precise definition of what might earn lecturers' promotion has been discussed by professor Jon Frode Blichfeldt (2010). His proposal for a framework for understanding the "academic labour" a 1.lecturer should amount to can briefly be described as "transdisciplinarity" "...drawing on a diverse array of knowledge resources and configuring them according to the problem at hand" (p.259). Blichfeldt expands his notion by pointing at how it encompasses a context of application, social and environmental contexts, integration of research and clinical experience, as well as patient/client/studentexperiences: "..the kind of knowledge developed while and by doing, by handling a practical situation within your professional domain." (p.259). Blichfeldt points towards a number of sources of inspiration: Olav Eikeland, John Dewey, Donald Schøn, Dreyfus \& Dreyfus, Lave \& Wenger and Richard Sennet. In the Norwegian context, Bjørke \& Braut (2009) and Engelsen, Moser \& Wittek (2013) offer similar expositions of a scientific rationale for this career path in the academic labour. Internationally, "the practice turn" has become a common notion of a "practice theory" (Schatzki, 2001), which entails a broad spectrum of contemporary theorists such as Bourdieu, Giddens, and resting on philosophers like Heidegger and Wittgenstein. As Schmidt (2018) notes, this field of practice theory covers a wide range of inputs, which in his view sometimes confuses more than it unveils.

\section{MAKING THE LOW ROAD HIGHER}

In the practical sense, our experience as assessors for applicants, we tend to make sure that the "insider epistemology" of the 1.lecturer is aligned with what theoretical inputs from contributions from Elliot Eisner (1985), Molander (1993), Polanyi (1966) and Nonaka \& Takeuchi (1995). Eisner's «connoisseur», who over years of handling the fruits and harvest of teaching has developed an expertise or intuitive sense that helps her to apply it to the situations that might occur. The connoisseur makes the right decisions, based on theoretical and practical insights - and relies on an intuitive ability to catch the moment or situation. Molander (1993) provides the example of the master boat builder to understand the skills of a non-academic, reflective practitioner, with the proper insider epistemology. The boat builder can judge the quality of a plank by smelling, watching, analysing the structure and surface, whether it will serve well as an addition to the floor or bulkhead. Further, what Michael Polanyi (1966) termed "personal knowledge" and "tacit knowledge» is difficult to discern and present as «explicit», and is a recurring matter in the assessment of the applicants' portfolios. Nonaka \& Takeuchi (1995) approach to unveil the four degrees or levels of tacitness: socialization (from tacit to tacit), externalization (from tacit to explicit), combination (explicit to excplicit knowledge) and internalization (from explicit to tacit) is also deemed helpful. Documenting the competency of a 1.lecturer implies that the implicit and tacit is unveiled and exposed. To operationalize this applicants need to demonstrate experience, reflection and analysis of actions taken, principles, presenting written material such as textbooks, webpages, lab routines, excursion plans etc., samples of exams, cases, experiments, formative assessment practices, student evaluations, curriculum reviews, placements and practice involvement, supervision and guidance practices, etcetera. Last it should also display the applicants' efforts to make students better prepared for worklife, by making studies more realistic and relevant for future employment.

\section{A Sounder Investment?}

For every PhD candidate in Norway a significant sum of between 3-5 million nkr (3-500000 Euros) is invested. Practically all of them are on accredited $\mathrm{PhD}$-programmes provided by the HE-institutions. The process and progression of the programmes are highly regulated and organized, supervised and accredited by national authorities under the auspices of the Ministry of Higher Education. Annually about 1600 candidates qualify for the $\mathrm{PhD}$-degree of which a little less than $40 \%$ continue a career in HE-institutions,

approximately 640 persons (Relling, R.B., Madsen, A.Å, \& Ulvestad, M.E.S. (2020) Doktorgradsundersøkelsen 2019). The vast majority of the almost 1000 1.lecturers in the publicly financed higher education were a) already recruited, b) performed their duties in regular working conditions (some 
with very moderate financial support over a semester) and c) remained in the institution. The cost amounts to almost zero in comparison.

A continual criticism of the $\mathrm{PhD}$-degree-training is that it hardly gives any preparation for teaching in HE. As of 2019 they will need to comply with a short $200 \mathrm{hrs}$ programme of teacher preparation to be tenured, which will alleviate some of the obvious shortcomings. Second, the doctoral training is a very specialized endeavour operating on the breaking round of the frontier of research in the field, implying that the scope is mostly narrow, specific and original. The theoretical foundation is strong and the training is rigorous in the methods and empirical domains of the subject.

However, while the Norwegian Higher Education system offers numerous $\mathrm{PhD}$ programmes for recruitment to a conventional career of 1.amanuensis (senior lecturer/associate professor/professor) unified support or programme for the teaching career has never been suggested, let alone supported by the Ministry.

The effect is that the number of persons employed at the entry level as lecturers, has grown steadily to about 3800 (including private HE institutions), while the percentage of the 1.lecturers is declining - from 9 to 7 percent over the recent years ${ }^{5}$. The vast majority of lecturers therefore has a career path that is unstructured and unstable. The political implication is that a significant separation of the working conditions for those with a $\mathrm{PhD}$ and those without is being widened. While the 1.amanuensis/professors in general are allowed up to $50 \%$ of their time for research at the level they find suited, the lecturer/1.lecturer are allowed significantly less time (15-25\%) for research.

\section{PREVIOUS INITIATIVES FOR PROMOTION OF A CAREER DEVELOPMENT PLAN FOR LECTURERS}

Since the Ministry of education gave out a set of regulations for careers in higher education in 1995, the lecturers that aimed to qualify further could embark on a path that followed to become a 1.lecturer. The first steps on that path were not much sought. In 1995 only 16 persons had a position of 1.lecturer. It was not until 1999 that the first HE institution established a formal programme to support lecturers to become 1.lecturers; The University College of Oslo (UCO), a predominantly professional training college for nursing, social work, art, teacher training, engineering, and so forth. In the following decade a number of similar, smaller institutions followed their initiative, and participated in a series of regular meetings and conferences, organized by the UCO. However, a number of reforms of the sector, first "a quality reform" that followed the Bologna policy strictly, took much attention, and one item in particular: the announcement of university colleges to seek status as full universities. Following this, a new quality assurance agency was established to ensure that applicants would fulfil the requirements for qualifications in the workforce. The need to raise the formal level of qualifications centred around elevating lecturers to 1.lecturers and recruitment of $\mathrm{PhD}$-candidates to 1.amanuensis. Second, a policy paper opened for a grand process of merging university colleges, in order to become a fully fledged university in 2008. The requirements for being accepted as a university was strictly dependent on the establishment of PhD-programmes, and after a few years, also on the output and productivity of research programmes hosting the Phd.

The efforts on bringing the number of staff up to a sufficient level to establish and run BA and MA programmes were beneficial for the initiatives for career promotion programmes for lecturers. In particular did professional schools develop programmes for 1.lecturers in the line of what UCO established. By the year 2000, the number had escalated to 359, and by 2012, 857 persons reached this level of competency (Engelsen, Moser \& Wittek, 2013). The numbers rose slowly to 937 in 2019. In 2013, 11 out of 17 professional teacher education programmes had established courses supporting lecturers aiming for a promotion to 1.lecturer, and four of the 17 had closed down their initiatives (Engelsen, Moser \& Wittek, 2013). Only three of these schools had programmes established for themselves while the remaining ran projects with other institutions, collaborating on a pragmatic common ground. The picture showed a very mixed bag of initiatives funded on each and one institution's defined needs.

The report provided by Engelsen et.al. (2013) note that the rationale for running these programmes were predominantly pragmatic. The need for raising the level of formal competence to meet the standards and demands of the accreditation organs was the one most often given. Just one programme offered any 
description of the basic ideas about the epistemological and ontological foundations of the 1.lecturer's position in higher education. The programmes offered were also predominantly of a technical and pragmatic nature. Support for writing reports, orientation about the regulations, etc. dominated the course offerings.

It is interesting to note that the Ministry has not shown any interest in promoting this career path in any other way than providing regulations and formal frameworks. While strongly promoting a rapid expansion of $\mathrm{PhD}$-programmes, and thereby also the 1.amanuensis/professor path through a number of initiatives and programmes, the notion of "1.lecturer" is hardly used in policy papers, white papers or analysis

\section{CHANGES IN STATUS?}

To find out more about the current situation for how "the low road" is being supported by the independent institutions in 2021, we approached 10 geographically dispersed HE-institutions (6 universities in the Southern part, two university colleges in Eastern and Western part, one University in Middle-Norway and one university in the North).

We posed the following questions:

1. Are your institution practicing parallel career paths?

2. Are your institution currently offering a program or any sort of systematic support for the career path to 1.lecturer?

3. If, so, how is it organised?

Of the 10 institutions seven did support parallel career paths, while two acknowledged the parallel paths, but did not support personnel aiming for the path to 1.lecturer or docent.

The institutions had very different policies. The two oldest universities (UiO, UiB), which never had gone through any merger after the reform proposal in 2008, had not even suggested to have a programme, nor implemented any policies for it. Some institutions had run programmes previously but abandoned the formal programmes (UIS \& OsloMet \& NTNU). Still, at the faculty/school level, they had retained a programme on a lower administrative level. One university was contemplating an institution wide programme (UiA). Some institutions had never had a programme on the institutional level but had faculties that had established programmes on their own (USN \& HVL). Two institutions had established institutionwide programmes and still supported them (HINN \& UIT).

The main difference here is the adoption of a programme on an institutional level. As we see, there are several approaches to the matter. Even if there was no support from the top university level, some professional schools (predominantly nursing and teacher education) had organized some support systems by giving economic support to hire substitutes for a short periode to alleviate time for writing and courses for supporting academic writing. Four institutions offered courses- in a programme - that dealt with the substantial dimensions such as practice theories, philosophy of knowledge production, reflexivity and action research (HINN \& USN, UiT, UiA). Some of these had experienced some ambiguity on the policy level about how to continue/develop the initiatives.

Our analysis displayed a rather disorganized system of efforts, with some important commonalities. In the papers presenting their efforts, again, the pragmatic dimension of expanding the number of persons with an acknowledged competency was the main concern for the written documents.

The small investigation show that few institutions have managed to maintain both the pursuit for a fully fledged university and upholding the support for a career path towards 1.lecturer. Our institution (INUAS) and UiT are the exception to having retained a full programme, while some other HE-institutions have surviving minor initiatives linked to specific faculties, predominantly at professional schools (nursing, health, teacher education).

\section{The Neglected Career Path}

The Ministry issued a white paper for the parliament in 2017, called "Quality Culture in Higher Education" (Ministry of education, 2017) the term 1.lecturer occurs only three times, and docent only once. While the overall message and aim of the white paper was to promote the importance of elevating the status of teaching in relation to research, the 1.lecturer was hardly mentioned. A Green paper published by the 
Ministry in 2018 proposed that the career path altogether was suffering from such "ambiguity regarding criteria, career trajectories and the actual application by the entire HE-sector regarding its interpretations and use" that it should be abandoned altogether.

However, in the public discussion in Norwegian higher education one cannot detect many signs of a discourse about the 1.lecturer. There are occasional reflections of a concern for the career path in the newsletter for major unions and the national journal for studies in higher education. One result of a merger was the Norwegian University of Technology and Science (40 000 students). The then rector Gunnar Bohwim realised that overtaking three smaller university colleges for applied sciences meant adopting a larger number of lecturers and 1.lecturers, claiming a voice not heard in the former conventional university.

The largest union published a report in 2016 among its members that $40 \%$ of the lecturers aimed at the position as 1.lecturer, but lacked financial and administrative support to do the tasks required to follow this path. The union also opposed the proposal of the Green paper strongly claiming that the career path needed support to expand rather than being the neglected - or shunned alternative.

The organization of Norwegian Universities (UR) suggested that the qualification path for 1.lecturer could be included as a regular PhD-programme in a Green Paper from 2012. The Ministry has never responded to this invitation and leaves it to the institutions to establish promotional programmes for this career path. The theoretical underpinning for such programmes is, in this national context in dire needs of a more clearly expressed foundation of what it means to possess a mastery of teaching and learning, and how it may find suitable expressions in the academic institution.

The criticism of the present design of PhD-programmes is based on the fact that only $40 \%$ of them are entering higher education after their training, and they are trained to work in a highly specific research area and not to fit a job as a teacher. The training programmes have a rejection rate of $40 \%, 62 \%$ complete within the time frame offered and the candidates often suffer from being left alone and facing challenges regarding their mental health. We find it difficult to suggest this scheme as a good solution to «our problem» - unless we are able to design a programme that builds on a different set of assumptions and premises.

\section{THE QUEST FOR A NORWEGIAN PROFESSIONAL DOCTORATE PROGRAMME FOR TEACHING AND LEARNING IN HIGHER EDUCATION}

At the time being, a number of institutions run programmes for the support of developing their employees' competence to the required 1.lecturer level. Some institutions have had and yet closed down programmes. Consequently, the status of the position is insecure and suffers from a fatigue of trust and prestige. As research became professionalized in Norwegian HE the division between the teaching staff and researchers grew stronger, and at the UiO the position of «lecturer» was kept to service the boom of the early 1990-ies, while the more advanced level became shunned - and almost disappeared. It was rediscovered when a revision of HE laws and regulations gradually turned teacher education, nursing and engineering colleges into universities of applied sciences. These new institutions had huge numbers of lecturers, and career policies simply demanded an advanced level. The ministry got involved and created formal specifications for a two-career pathways in HE.

In 2006 the «dosent» was placed as the advancing level for the 1.lecturer - defined as a professorial level, and translated to «professor» in English.

While huge investments have been made to establish PhD-programmes and the race for status and achievements have been closely aligned with the number of candidates and completed $\mathrm{PhDs}$ - nothing has been done from the Ministry to support the development of the career paths for lecturers underway to 1.lecturer.

The association for Norwegian HE institution (Vøllestad et.al., 2012) produced a report in 2012 which opened for an expansion of the genres for documentations typical of a portfolio for 1.lecturer candidates. This paved the way for the 1.lecturers to acquire a $\mathrm{PhD}$ based on the genres they would be familiar with: reports rather than academic papers, reflection notes rather that book chapters etc.

In light of what seems to be structural problems with the present $\mathrm{PhD}$, the dilemma is evidently whether this alignment will be a solution - or - adding to the problem. 


\section{CONCLUSION}

Our analysis of historical documents and the present empirical situation is an attempt to construct an argument based on a heuristic of the two career paths to the top qualification levels in Norway, both translated to "professor" in English. One is built on experiences from a trajectory that contains a lot of teaching students, participating in development work (D in the R\&D), servicing the institution and work for the wellbeing and success of students - leading to the "Docent". The other is the more conventional path through more research (the R in R\&D). We cannot from our material claim that the career path leading to a title of 1.lecturer and docent is shunned, but we can see that for some institutions it is both lost and found. Two institutions never quite lost it and maintain active and supportive policies for the promotion of the alternative. While it seems to be a pattern that at the School/Faculty level there is an expressed need for employed academics with the experience and background that is useful for teaching -in particular professional studies. However, the title 1.lecturer initially emerged from the need for effective training in skills for work in laboratories and a number of disciplinary studies in the humanities, social sciences as well as medicine, odontology and other health studies.

The policy of our government clearly favours the $\mathrm{PhD}$ as the route to higher qualifications and is demonstrated by the almost total absence of any support or acknowledgment of the title in government reports or policy documents. In addition, they finance the PhD-programmes of the institutions very generously, while no incitements are offered to the alternative career. In spite of the public support a number of institutions have sought to establish and maintain a programme, or some institutional to support those academics who prefer this road to higher formal status. This implies that on the organizational level there is a wide acknowledgement of the need for having complimentary competencies represented in the staff. To borrow from a notion from gestalt theory, they realise that the sum of two entities often add to more than the sum.

The holistic thinking of the Humboldtian idea, in which teaching and research were combined in the search for impartial truth, is based on the same presumption of the fruitful and fertile coexistence of the scholarships that promote both concerns of the academic vocation. We think that closing down programmes for 1.lecturers will be detrimental to the idea once proposed by the Humboldtian institutions. Second, it will narrow the career options for about 3800 persons presently employed as lecturers and degrades their present status and hampers their motivation for future work in higher education. One possible path is to open present $\mathrm{PhD}$-programmes to include the practical and professional scholars to a doctoral study that signifies their epistemological and ontological positions.

"Only he who takes the first step can find new paths, while those who tread in the footsteps of others cannot choose their direction."

\section{ENDNOTES}

1. https://www.uhr.no/_f/p1/i01dd863b-eb73-4b15-a926-fa5f728df736/endelig_versjon_veiledning_dosentjuni2007.pdf

2. https://www.uhr.no/_f/p1/i5a9ceb87-f2ad-425b-a027-7cebf4294986/veiledning-for-deg-som-vil-sokeopprykk-til-forstelektor-november-2007.pdf

3. https://www.uhr.no/f/p1/ie784672d-7e0e-4ae3-a60f-482713a4618c/endelig_versj_veiledn_retningslinjerforstelektoropprykk-desember2006.pdf

4. The UR uses the expression for the PhD-approach as the "Outside-looking-in-perspective", while "Insidelooking-out-perspective" would be more typical of the 1.lecturer (and dosent)

5. https://dbh.nsd.uib.no/statistikk/rapport.action?visningId=137\&visKode=false\&admdebug=false\&columns $=$ arstall\&index $=1 \&$ formel=329\&hier=insttype!9! instkode!9!fakkode!9!ufakkode!9!st_kode \&sti=\&param= arstall\%3D2020!8!2019!8!2018!8!2017!8!2016!9!st_kode\%3D1008!8!1009!9!dep_id\%3D1 (downloaded 22.01.21)

6. https://khrono.no/laerere-arbeidsliv-forstelektor/8-av-10-vil-ha-opprykk-men-fa-ser-muligheter/150952). 


\section{REFERENCES}

Bachke, C.C. (2020). Fakta, frustrasjoner og forbedringspotensialer. En undersøkelse av dagens norske dosentstilling. In C.C. Bachke \& M. Hermansen (Eds.), Å satse på dosenter: Et utviklingsarbeid (pp. 56-78). NOASP.

Bjørke, G., \& Braut, G.S. (2009). To karrierevegar - Jamstilte, men ulike. Uniped, 32(4), 40-50.

Bjørke, G., \& Habib. L. (2011). From A Career Development Programme to Professional Doctorate or Practice-oriented PhD: A Norwegian Case Study. Work Based Learning e-Journal, 2(1), http://wblearning-ejournal.com

Blichfeldt, J.F. (2010). On knowledge bases and maps of knowledge: Some quiddities on getting to know in contemporary higher education. Nordic Studies in Education, 30(4), 252-265.

Eisner, E.W. (1985). The art of Educational Evaluation. A person View. London: The Falmer Press.

Engelsen, K.E., Moser, T., \& Wittek, A-L. (2013). «... på nivå og omfang med ...» Førstekvalifisering gjennom førstelektorløp - en analyse basert på erfaringer fra lærerutdanningene. Uniped, 36(4), 109-124.

Kari Smith, K.H., \& Skjeldestad, K. (2020). Universitetslektorer - en neglisjert profesjonsgruppe? Uniped, (4), 280-297.

Kvittingen, I. (2008). Professor før 40. Forskerforum, 40(4), 12-17.

Kyvik, S., \& Olsen, T.B. (2009). Gjennomstrømming i doktorgradsutdanningen. NIFU-Step rapport nr. 40 .

Ministry of education. (2017). Kultur for kvalitet i høyere utdanning [Quality culture in Higher Education]. White paper for the Norwegian Parliament, 16.

Molander, B. (1993). Kunskap i handling. Göteborg: Bokförlaget Daidalos.

Nicolini, D. (2013). Practice theory, Work and Organization: An Introduction. Oxford: Oxford University Press.

Nilsen, Y. (2005). En sterk stilling? Norsk forskerforbunds historie 1955-2005. Bergen: Vigmostad \& Bjørke.

Nonaka, I., \& Takeuchi, H. (1995). The knowledge-Creating Company. New York: Oxford University Press.

Pettersen, R.C. (2020). Den tilfeldige dosent. Fra praktisk reformering av høgskolestudier via lærebokpublisering til forskning og faglitterært forfatterskap. In C.C. Bachke \& M. Hermansen (Eds.), A satse på dosenter: Et utviklingsarbeid (pp. 107-118). NOASP.

Polanyi, M. (1966). The Tacit Dimension. London: Routledge \& Kegan Paul.

Relling, R.B., Madsen, A.Å., \& Ulvestad, M.E.S. (2020). Doktorgradsundersøkelsen 2019. NIFU-rapport 19.

Schatzki, T.R. (2001). Introduction: Practice theory. In T.R. Schatzki, K.D. Knorr-Cetina, \& E.V. Savigny (Eds.), The Practice Turn in Contemporary Theory (pp. 10-23). London and New York: Routledge.

Schmidt, K. (2018). "Practice theory": A critique. In V. Wulf, et al. (Eds.), Socio-Informatics: A Practicebased Perspective on the Design and Use of IT Artefacts. Oxford: Oxford University Press.

Vøllestad, N.K., Fretland, J.O., Fuglseth, A.M., Habib, L., Malterud, N., Ringdal, O., . . Vinje, J-W. (2012). Én ph.d.-grad for fremtidens behov? Kunnskap, ferdigheter, generell kompetanse. Oslo: Universitets- og høgskolerådet. 